\title{
Development and Research Status of Heavy Oil Enhanced Oil Recovery
}

\author{
Liang Xue, ${ }^{1}$ Pengcheng Liu $\mathbb{D}^{2}{ }^{2}$ and Yun Zhang ${ }^{3}$ \\ ${ }^{1}$ Shengli Oilfield Petroleum Development Center Co., Ltd., Dongying 257000, China \\ ${ }^{2}$ School of Energy Resources, China University of Geosciences, Beijing 100083, China \\ ${ }^{3}$ Research Institute of Petroleum Exploration and Development, SINOPEC, Beijing 100083, China \\ Correspondence should be addressed to Pengcheng Liu; liupengcheng8883@sohu.com
}

Received 5 September 2021; Accepted 27 December 2021; Published 12 February 2022

Academic Editor: Xiaofei Sun

Copyright (C) 2022 Liang Xue et al. This is an open access article distributed under the Creative Commons Attribution License, which permits unrestricted use, distribution, and reproduction in any medium, provided the original work is properly cited.

Heavy oil is an important part of petroleum hydrocarbon energy. With the depletion of conventional crude oil reserves, successful and efficient exploitation of heavy oil resources is becoming increasingly important. This article focuses on the nine relatively mature heavy oil development technologies from the perspectives of the level of understanding of the mechanism and the scale of the mining field: steam huff and puff, steam flooding, steam-assisted gravity drainage (SAGD), in situ combustion, thermochemical combined flooding, multicomponent thermal fluid, polymer flooding, chemical viscosity reduction development, and microbial oil recovery, which are divided into two technical categories: thermal recovery and cold recovery development. The basic development principles are explained, and application examples of the two categories of techniques are provided. It is pointed out that thermal compounding, cold mining development, and nanomaterial applications will be the three development trends in heavy oil development.

\section{Introduction}

According to the classification method of the United Nations Institute for Training and Research (UNITAR), crude oil with a viscosity of $>100 \mathrm{MPa}$ s or a relative density of $>0.934 \mathrm{~g} / \mathrm{cm}^{3}$ is generally defined as heavy oil, which can be divided into two categories: heavy oil and asphalt (oil sands). Heavy oil resources are very rich in the world, with geological reserves of about 815 billion tons, accounting for $70 \%$ of crude oil reserves. It is an important replacement material for oil development and is mainly distributed in Canada, Venezuela, Russia, the United States, and China [1-3]. At present, with the depletion of conventional crude oil reserves, the successful exploitation of these heavy oil resources is becoming increasingly important. Heavy oil development can generally be divided into two technical categories, thermal recovery and cold recovery development. This article introduces the basic principles in detail and describes application examples of the two categories of techniques. In addition, it is pointed out that thermal compounding, cold recovery development, and nanomaterial applications will be the three trends in heavy oil development.

\section{Heavy Oil Thermal Recovery Techniques}

Thermal recovery is a heavy oil development technique in which heat transfer media are injected into the oil layer or are burned on-site to generate heat. The heating is used to reduce the viscosity of the crude oil and enhance its fluidity. This technique is currently used in heavy oil reservoirs in China and abroad. These are the most commonly used and most effective mining methods. Thermal recovery began in the 1930s, represented by applications in the United States and Canada, and four techniques have been successively developed-steam flooding, steam huff and puff, fired oil layer, and steam-assisted gravity drainage (SAGD) - which are mainly used in medium-shallow-layer $(<600 \mathrm{~m})$ and thick-layer heavy oil [4-6]. These four techniques also constitute the basic form of current heavy oil thermal 
recovery development. In China, thermal recovery was introduced in the 1980s. In view of the characteristics of deep reservoirs, steam huff and puff, steam flooding, SAGD, and in situ combustion were developed for medium and deep reservoirs $(<1400 \mathrm{~m})$, of which steam huff and puff production accounted for the largest thermal recovery output. Currently, this main technical form accounts for $76.1 \%$ of heavy oil development in China [7,8]. At the end of the last century, as the newly discovered onshore heavy oil resources were depleted (deeper buried, thinner reservoirs, and higher viscosity) and offshore heavy oil reservoirs were put into development, thermal recovery techniques were further developed, and some new thermal power technologies were created. Oil production development technology includes thermochemical compound development [9] and multielement thermal fluid development [10]. According to the characteristics of the different processes and the adaptability of the reservoir, the heavy oil thermal recovery techniques can be classified in detail (Table 1).

2.1. Steam Huff and Puff. This technique is a method of heavy oil recovery in which a certain amount of hightemperature, high-pressure saturated steam is injected into an oil well, and the heat it carries heats the crude oil, reducing its viscosity and improving its fluidity. This includes the three processes of steam injection, simmering, and opening of wells, which can be recycled for several cycles. The technical method is characterized by quick results, a low investment, and wide application, and it is the main form of hot production at present. However, due to its limited heating radius, the ultimate recovery rate is not high, generally around $25 \%[11,12]$. Heavy oil reservoirs usually require changing the development methods after steam huff and puff, such as steam flooding and fire flooding, in order to further improve the oil recovery of the reservoir.

2.2. Steam Flooding. This technique involves continuously injecting high-dryness steam into the oil layer through the injection well, and the steam continuously heats the oil layer, thereby greatly reducing the viscosity of the formation's crude oil. The injected steam transforms into a hot fluid in the formation, which drives the crude oil around the production well and is recovered to the surface. It is an important technique and greatly increases the recovery of heavy oil reservoirs. Its recovery rate can generally reach more than 50\% [13]. The Coen River in the United States and the Duri oil field in Indonesia have employed this technique to achieve recovery rates of more than $60 \%$ (Figure 1 ). In order to adapt to the development of deep heavy oil reservoirs in China, related techniques such as insulated pipe strings and high-dryness steam injection boilers are used to extend the limit of the steam flooding to $1400 \mathrm{~m}$ [14-17].

2.3. Steam-Assisted Gravity Drainage. Steam-assisted gravity drainage involves injecting steam into the steam injection well. The steam is overlain upward to form a steam cavity in the formation. The steam cavity expands upward and laterally to exchange heat with the crude oil in the oil layer. The heated crude oil and steam condensate water rely on gravity. The effect is released into the horizontal production well below. Overseas SAGD projects have mainly been based on the dual horizontal well combination model (Figure 2). The burial depth of the reservoir is less than $500 \mathrm{~m}$, and the thickness of the reservoir is generally greater than $15 \mathrm{~m}$ [18]. The Liaohe Oilfield has expanded the application of the SAGD technique to 1 , forming a combined vertical wellhorizontal well combination SAGD model in Block Du 84 (Figure 3). The reservoir has a burial depth of $640-810 \mathrm{~m}$, a reservoir thickness of 30-100 m, and a crude oil viscosity of $21 \times 10^{4} \mathrm{MPa}$ s. The water cut before the conversion was $76 \%$, and the recovery level was $22 \%$. Thirty-one vertical steam injection wells were deployed in 2005, along with eight horizontal production wells. After commissioning, the daily oil production increased from 278 tons before the implementation to 491 tons in 2017, and the recovery rate is expected to increase by $34.13 \%$ over the throughput. At present, this technique is suitable for the expansion of the burial depth of the reservoir from $500 \mathrm{~m}$ to $1000 \mathrm{~m}$, and it is an important production form for thick-layer, weak edge, and bottom water special/super heavy oil $[19,20]$.

2.4. In Situ Combustion. This technique is a clean method of improving the recovery of high-viscosity heavy oil. It is often used because it has many advantages over other thermal recovery methods. Research has shown that increasing the gas injection rate and the oxygen injection rate can increase the oil recovery rate. High permeability and high initial oil content play a positive role in this process. The steam zone and the hot water zone formed by combustion can displace the crude oil into the production well (Figure 4). The well test method of the in situ combustion system established using physical simulations has been applied to the mining field test, which solves the problem that the temperature of the combustion front cannot be monitored in real time onsite. This technique originated in the 1960s. Romania, the United States, Canada, and India carried out technical tests and applications of burning oil reservoirs. Among them, Romania's Suplacu oil field has been developed in flames for 50 years, with more than 500,000 tons of stable production for more than 30 years, and the expected recovery rate is over $65 \%$ [21-23]. In the Xinjiang Oilfield, tests were conducted in the abandoned Hongqian1 well area. The annual oil production increased from 4,000 tons before fire flooding to 91,000 tons, the oil production rate increased from $0.04 \%$ to $2.6 \%$, the cumulative oil production was 281,000 tons, and the staged recovery rate was $22 \%$ (Figure 5) [24].

2.5. Thermochemical Combined Flooding. This technique was developed and applied in the Shengli Oilfield at the beginning of the 21st century, and it implemented the idea of single steam injection heating for viscosity reduction and oil displacement. The created steam + chemical agent (hightemperature viscosity reducer, oil displacement agent) + gas $\left(\mathrm{CO}_{2}, \mathrm{~N}_{2}\right)$ auxiliary horizontal well thermochemical composite oil recovery method is shown in Figure 6. The main 
TABLe 1: Production characteristics and reservoir adaptability of the different heavy oil thermal recovery techniques.

\begin{tabular}{|c|c|c|c|c|c|c|}
\hline $\begin{array}{l}\text { Reservoir } \\
\text { properties }\end{array}$ & $\begin{array}{l}\text { Steam huff and } \\
\text { puff }\end{array}$ & $\begin{array}{l}\text { Steam } \\
\text { flooding }\end{array}$ & $\begin{array}{l}\text { Steam- } \\
\text { assisted } \\
\text { gravity } \\
\text { drainage }\end{array}$ & In situ combustion & $\begin{array}{l}\text { Thermochemical } \\
\text { combined flooding }\end{array}$ & $\begin{array}{l}\text { Multielement thermal } \\
\text { fluid technique }\end{array}$ \\
\hline Reservoir depth (m) & $65-1400$ & $<1400$ & $<1400$ & $150-1400$ & $<2500$ & $<2500$ \\
\hline $\begin{array}{l}\text { Oil viscosity } \\
(\mathrm{MPa} \cdot \mathrm{s})\end{array}$ & $>60$ & $50-100$ & $50-100$ & $>20$ & $<60$ & $<60$ \\
\hline $\begin{array}{l}\text { Effective thickness } \\
\text { of oil layer }(\mathrm{m})\end{array}$ & $>6$ & $>10$ & $>15$ & $3-15$ & - & - \\
\hline $\begin{array}{l}\text { Permeability } \\
\left(10^{-3} \mu \mathrm{m}^{2}\right)\end{array}$ & $>100$ & $>200$ & $>150$ & $>100$ & $>50$ & $>50$ \\
\hline $\begin{array}{l}\text { Permeability } \\
\text { coefficient of } \\
\text { variation }\end{array}$ & $<0.6$ & - & $<0.6$ & - & $0.64-0.75$ & $0.6-0.75$ \\
\hline Advantages & $\begin{array}{l}\text { Shallow well, } \\
\text { heavy oil }\end{array}$ & $\begin{array}{c}\text { Severe } \\
\text { heterogeneity }\end{array}$ & $\begin{array}{c}\text { Thick oil } \\
\text { layer }\end{array}$ & $\begin{array}{c}\text { Low vertical } \\
\text { permeability of } \\
\text { inclined oil layer }\end{array}$ & $\begin{array}{l}\text { Fresh water, high } \\
\text { acidity, heterogeneity }\end{array}$ & $\begin{array}{l}\text { Low temperature, } \\
\text { fresh water, high } \\
\text { acidity, heterogeneity }\end{array}$ \\
\hline Disadvantages & $\begin{array}{c}\text { Cracks, } \\
\text { heterogeneity }\end{array}$ & Cracks & $\begin{array}{l}\text { Cracks, } \\
\text { barriers }\end{array}$ & $\begin{array}{c}\text { Cracks, gas caps, } \\
\text { low porosity }\end{array}$ & Air cap, bottom water & Air cap, bottom water \\
\hline
\end{tabular}

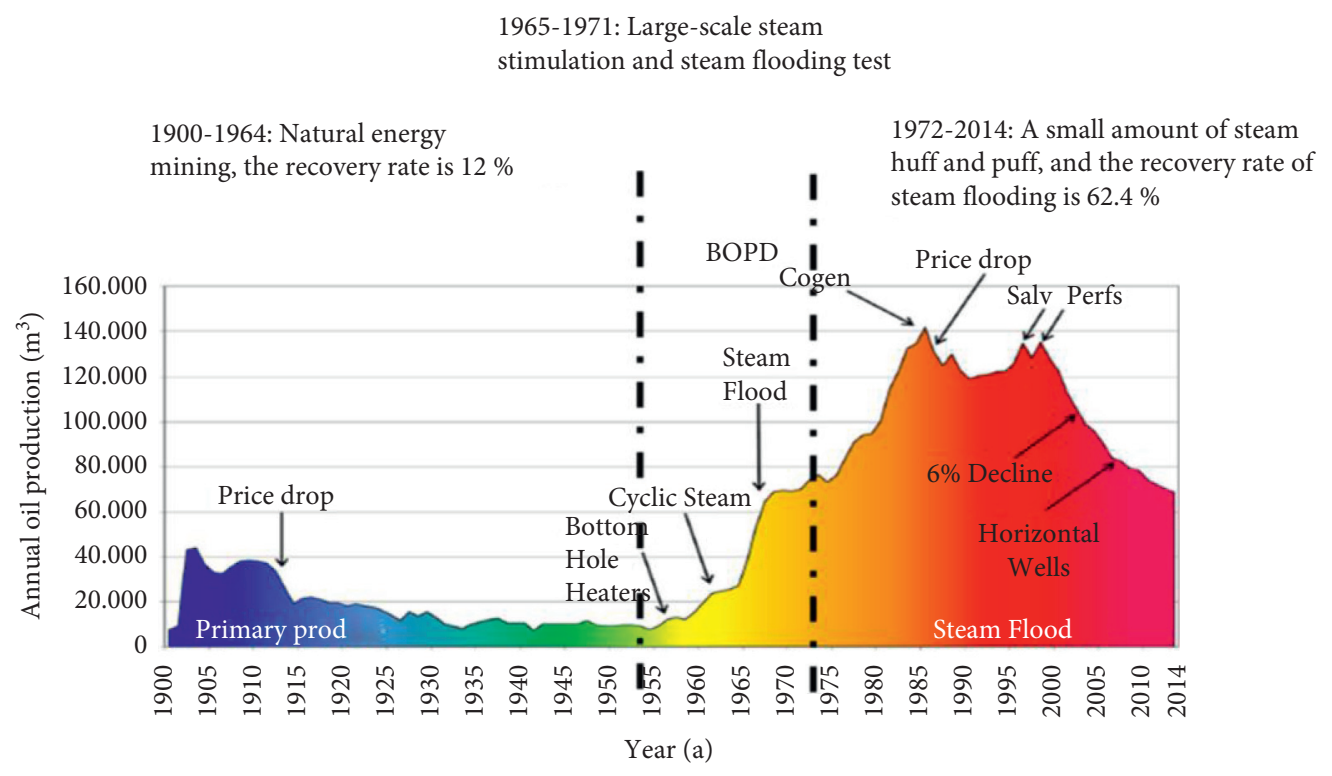

Figure 1: Annual oil production of the Coen River Oilfield.

development mechanism is as follows: vapor-agent coupling viscosity reduction, $\mathrm{N}_{2}$ heat preservation and energy enhancement, thermal agent replacement, and flooding assistance. That is, the near-well end uses steam heating to reduce the viscosity, and the far-well end relies on the viscosity reducer to chemically reduce the viscosity, which expands the oil drainage radius. Regarding the problem of a large amount of heat loss, the characteristics of low gas thermal conductivity and low density are used to form a lowpressure zone in the upper part of the reservoir. The heatconducting layer simultaneously prevents the rapid loss of heat, improves the heat utilization rate, and supplements the formation energy. As the steam expands from the wellbore to the oil layer, the temperature continuously decreases, and the oil washing effect weakens. The far-well end viscosity reducer has the oil washing effect of reducing the interfacial tension. The composite relay enhances the oil washing effect [25-29]. Laboratory experiments have shown that the oil displacement efficiency of thermochemical combination is $32.1 \%$ higher than that of single steam (Figure 7). In addition, related supporting technologies have been developed in the Shengli Oilfield, including thermochemical compound development numerical simulation software, a hightemperature-resistant oil displacement agent, a horizontal oil pump, and an integrated injection-production pipe string. Under the guidance of thermochemical complex development technology, the following three different technical forms have been developed for different reservoir types.

(1) Horizontal well, dissolver, $\mathrm{CO}_{2}$, and steam (HDCS) [30]: this method is mainly used in deep ultraheavy 


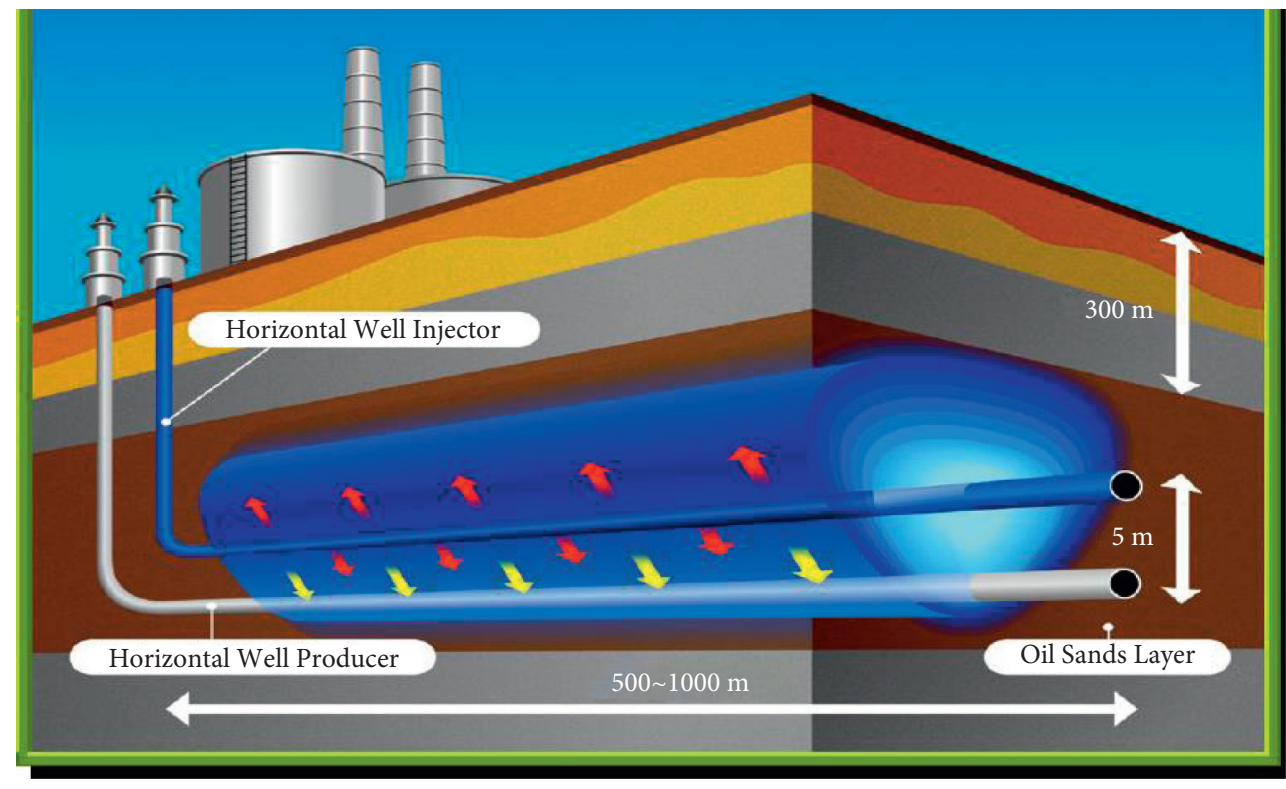

FIgURE 2: Schematic diagram of the SAGD oil production mechanism and basic well pattern form.

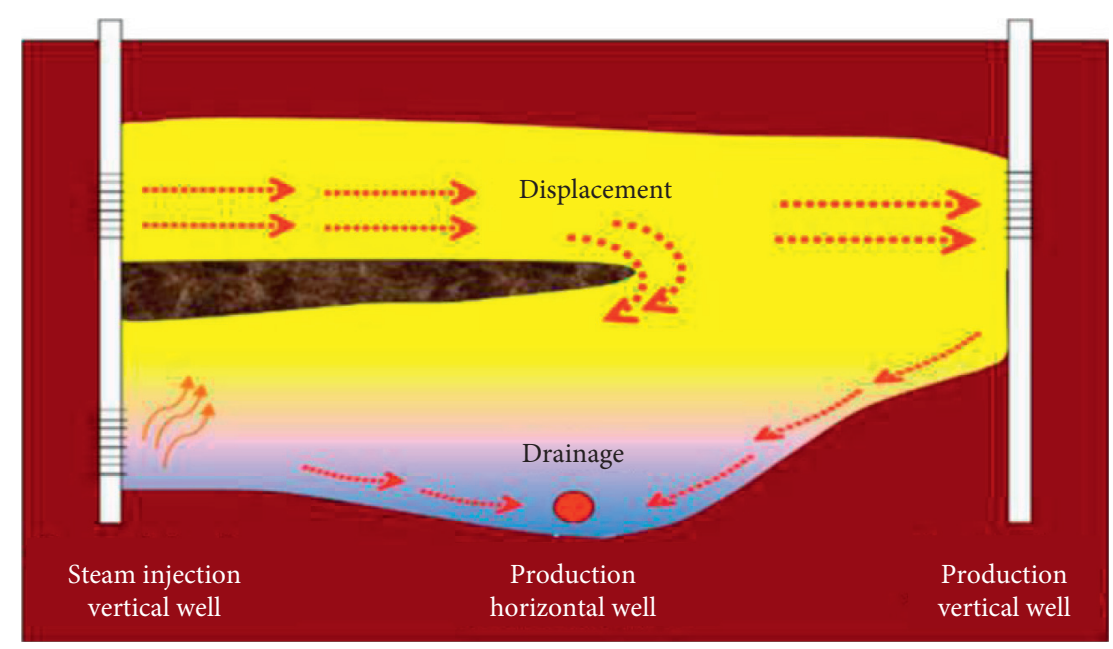

FIGURE 3: Innovation of the SAGD well pattern form.

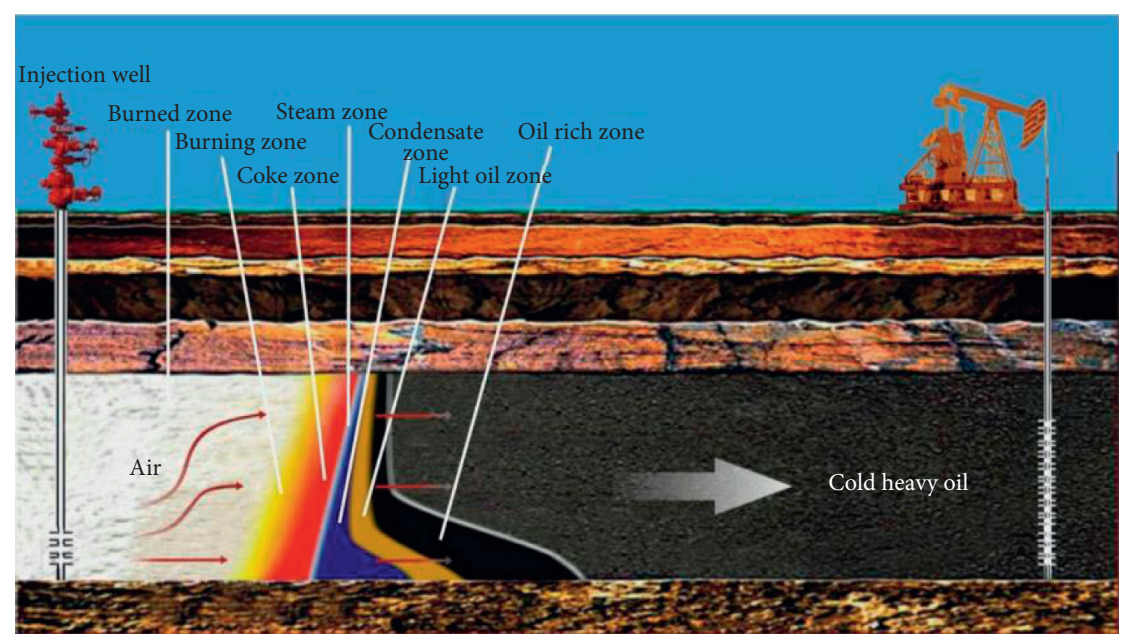

FIgURE 4: Schematic diagram of in situ combustion. 


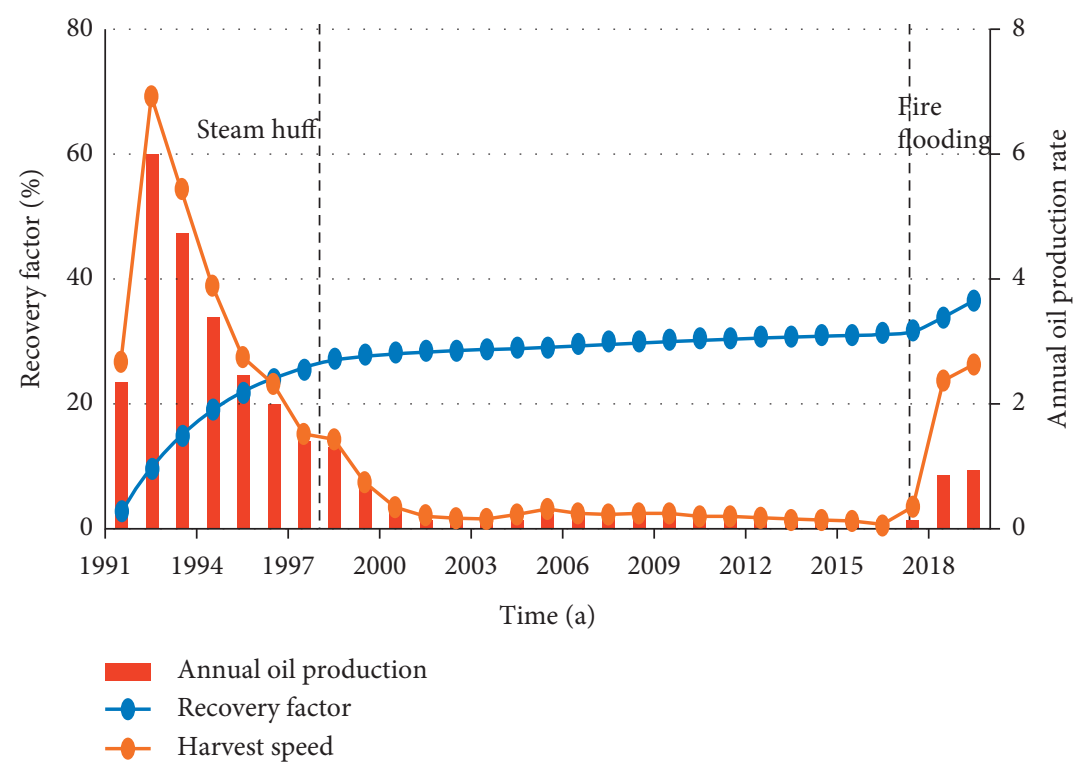

FIGURE 5: Variation curve of the production and oil production rate of the fire flooding industrialization test in the Hongqian1 district.

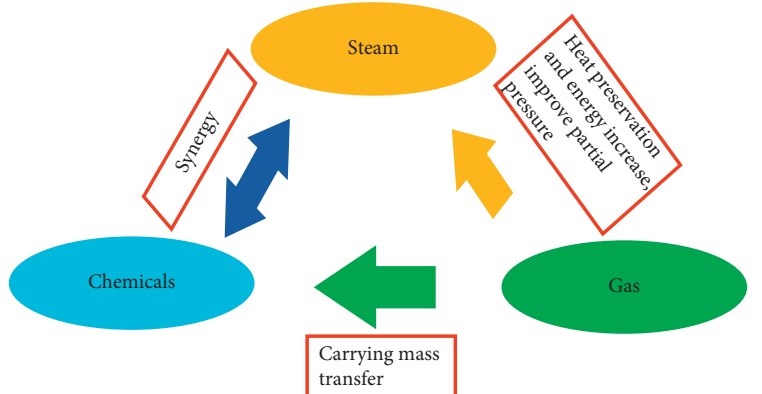

FIGURE 6: Schematic diagram of thermochemical combined flooding.

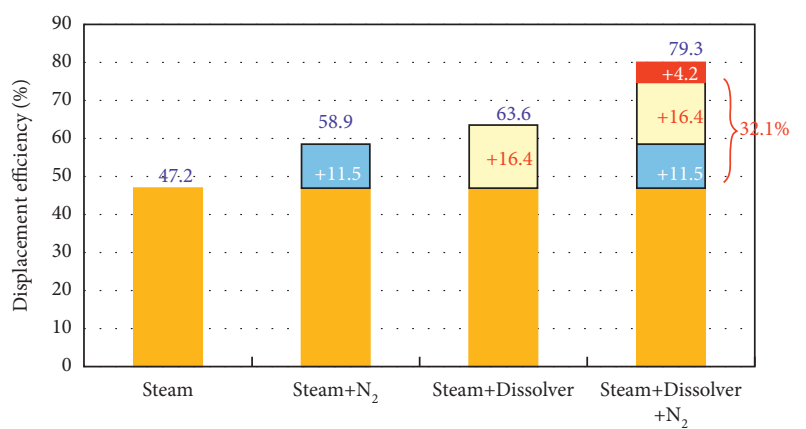

Figure 7: Comparison of the oil displacement efficiencies of the different displacement methods.

oil reservoirs. Taking advantage of the dissolution and viscosity reduction of carbon dioxide in deepseated heavy oil, the problem of noninjection and nonproduction in such reservoirs is solved using a composite method. The application of this technique in the Wangzhuang Oilfield has increased the cycle oil production of a single well from 127 tons to 1,812 tons, i.e., an increase of 13.3 times. The depth limit of heavy oil thermal recovery development can be extended to $2000 \mathrm{~m}$, and the viscosity limit can be increased to $20 \mathrm{MPa}$.

(2) Horizontal well, dissolver, $\mathrm{N}_{2}$, and steam (HDNS) $[31,32]$ : this method is mainly used in shallow and thin superheavy oil reservoirs. By utilizing the characteristics of $\mathrm{N}_{2}$, the problems of large heat loss and a small heating radius of this type of oil reservoir are solved. The application of this technique in the Shengli Chunfeng Oilfield has increased the cycle oil production of a single well from 82 tons to 1,484 tons. The thickness limit for ultraheavy oil development is reduced to $2 \mathrm{~m}$.

(3) Thermochemical combined flooding [33]: this method is mainly used in the process of converting deep heavy oil to steam flooding. Based on the small steam cavity, uneven displacement, and low oil displacement efficiency characteristics of the steam flooding process in this type of reservoir, the partial pressure of $\mathrm{N}_{2}$ is used to improve the dryness of the steam, foam agent plugging is used to achieve balanced displacement, and oil displacement agents are used to improve the oil washing efficiency. That is, the combined development method is as follows: steam $+\mathrm{N}_{2}+$ foaming agent + oil displacing agent. The Shengli Petroleum Administration Bureau selected four small well groups and four large well groups in the Gudao Oilfield for application. The recovery rate of the deep heavy oil steam flooding exceeded $60 \%$ (Figure 8 ), and the steam flooding pressure was increased from the industry-recognized $5 \mathrm{MPa}$ to $7 \mathrm{MPa}$.

2.6. Multielement Thermal Fluid Technique. This technique has been tested in the Bohai Oilfield since 2008 [34]. The offshore oilfield production platform has a high degree of 


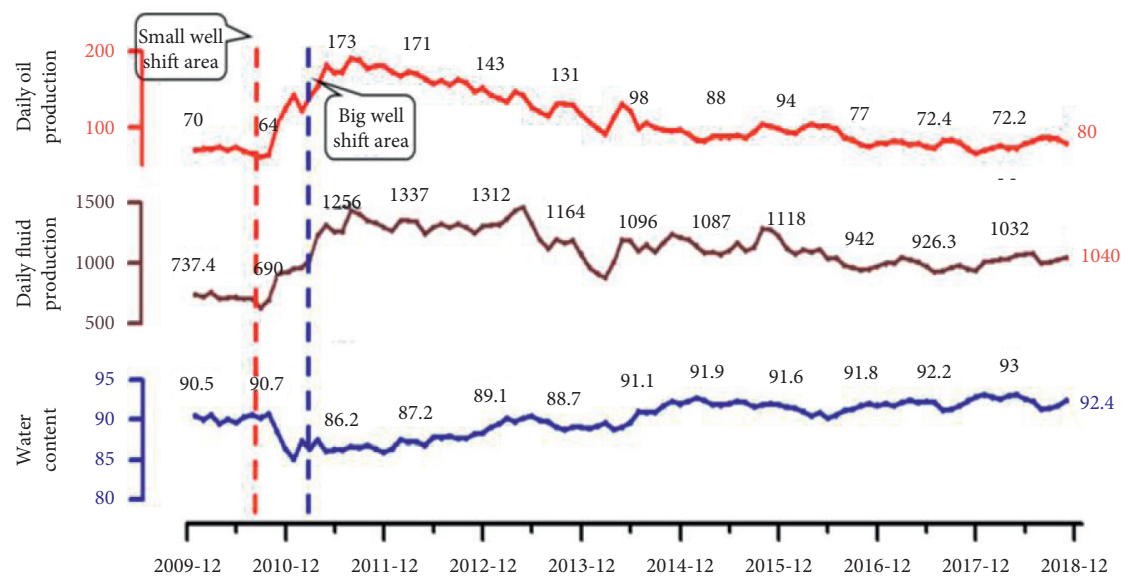

Figure 8: Oil production curve for thermochemical combination flooding of the test well group in the Gudao Oilfield.

integration and a compact structure. The traditional steam boiler has a large area and a heavy weight, and it cannot adapt to offshore operations. The multielement thermal fluid generator is based on the combustion and injection theory of the liquid rocket engine. It has a small footprint and meets the construction requirements of offshore platforms. The device (Figure 9) deflagrates a certain mixture ratio of fuel and oxidant in the combustion chamber to produce a hightemperature mixture. The mixture is composed of $\mathrm{N}_{2}, \mathrm{CO}_{2}$, and a small amount of $\mathrm{H}_{2} \mathrm{O}$, and the multielement thermal fluid is a mixed gas. The main mechanisms for enhancing oil recovery are viscosity reduction via heating, viscosity reduction via gas dissolution, and gas pressurization. At present, this technique is the main form of heavy oil thermal recovery in offshore oil fields [35-38].

\section{Heavy Oil Cold Recovery Techniques}

Heavy oil cold recovery techniques, relative to thermal recovery, generally refer to the development of heavy oil without heating to achieve viscosity reduction. At present, there are three relatively mature methods: polymer flooding, chemical viscosity reduction development, and microbial oil recovery. These three methods have obvious differences in terms of their principles of action and their objects of action. According to the different process characteristics and reservoir adaptability, the heavy oil cooling techniques can be classified in detail (Table 2).

3.1. Polymer Flooding Development Technique. Polymer flooding mainly acts on the water phase and improves the oil-water viscosity ratio by increasing the viscosity of the water phase. This technique is mainly applied to thin oil reservoirs. According to the screening criteria of polymer flooding proposed in a previous study, polymer flooding is not suitable for application in heavy oil reservoirs with viscosities greater than $200 \mathrm{MPa}$ s [39-41]. Because heavy oil polymer flooding requires a higher concentration of polymer solution to effectively reduce the water-oil mobility ratio, this greatly increases the difficulty of polymer injection and the cost of chemical agents. However, in recent years, a

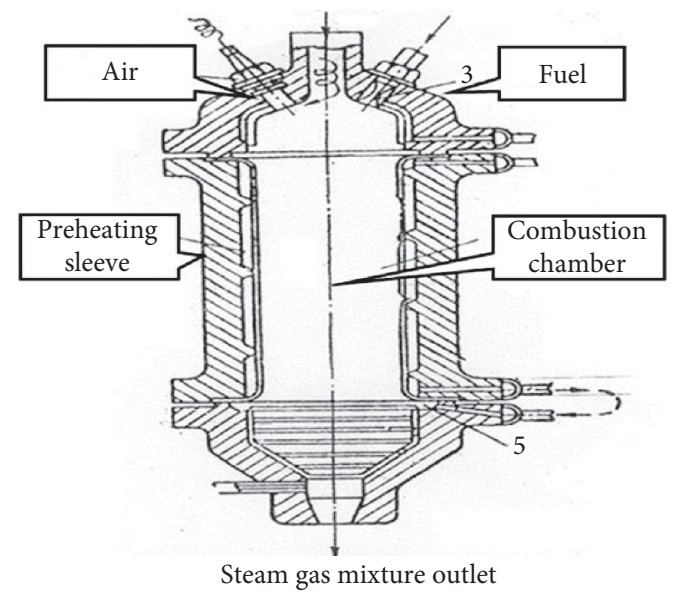

Figure 9: Multielement thermal fluid generator.

large number of indoor studies and field applications of polymer flooding have been carried out in Canada and the Shengli Oilfield to improve the heavy oil recovery, and significant results have been achieved.

Canadian Natural Resources Limited (CNRL) has implemented a fairly large-scale polymer flooding experiment in the Brintnell reservoir in the Pelican Lake oil field. The geological parameters of the Brintnell reservoir are as follows: oil layer depth of $300-425 \mathrm{~m}$, oil layer thickness of $1-9 \mathrm{~m}$, porosity of $28-32 \%$, permeability of $0.3-3 \mathrm{D}$, temperature of $13-17^{\circ} \mathrm{C}$, water saturation of $30-40 \%$, crude oil viscosity of $80-80000 \mathrm{MPa}$ s, and initial formation pressure of $1900-2600 \mathrm{kPa}$. It is characterized by a shallow oil layer burial depth, a small oil layer thickness, and a low temperature. Block HTLP 6 is the earliest pilot block in the Brintnell reservoir. It mainly adopts the horizontal well production mode. Among them, there are four injection wells and three production wells. The horizontal wells are $1,400 \mathrm{~m}$ long, and the well spacing is $100-185 \mathrm{~m}$. Figure 10 shows the changes in the crude oil production rate, polymer injection rate, and water cut over time since the HTLP 6 block began production in 1992. It can be seen that the oil production reached its peak in 2000, and the oil production continuously decreased thereafter. The polymer solution was 
TABle 2: Production characteristics and reservoir adaptability of different heavy oil cold recovery techniques.

\begin{tabular}{|c|c|c|c|}
\hline Reservoir properties & Polymer flooding development & $\begin{array}{l}\text { Chemical viscosity } \\
\text { reduction development }\end{array}$ & $\begin{array}{l}\text { Microbial enhanced oil } \\
\text { recovery }\end{array}$ \\
\hline Reservoir depth (m) & $65-1400$ & $<1400$ & $<2500$ \\
\hline Oil viscosity $(\mathrm{MPa} \cdot \mathrm{s})$ & $<60$ & $50-100$ & $<40$ \\
\hline Effective thickness of oil layer (m) & - & - & $>15$ \\
\hline Permeability $\left(10^{-3} \mu \mathrm{m}^{2}\right)$ & $>50$ & $>50$ & $>50$ \\
\hline $\begin{array}{l}\text { Permeability coefficient of } \\
\text { variation }\end{array}$ & $0.6-0.75$ & $<0.70$ & $0.64-0.75$ \\
\hline Advantages & $\begin{array}{l}\text { Low temperature, fresh water, } \\
\text { heterogeneity }\end{array}$ & $\begin{array}{c}\text { Low clay content, low water } \\
\text { hardness }\end{array}$ & $\begin{array}{c}\text { Low temperature, high acidity, } \\
\text { heterogeneity }\end{array}$ \\
\hline Disadvantages & $\begin{array}{c}\text { Bottom water, high gray matter } \\
\text { content }\end{array}$ & $\begin{array}{c}\text { Cracks, bottom water, } \\
\text { heterogeneity }\end{array}$ & $\begin{array}{l}\text { Air cap, bottom water, } \\
\text { heterogeneity }\end{array}$ \\
\hline
\end{tabular}

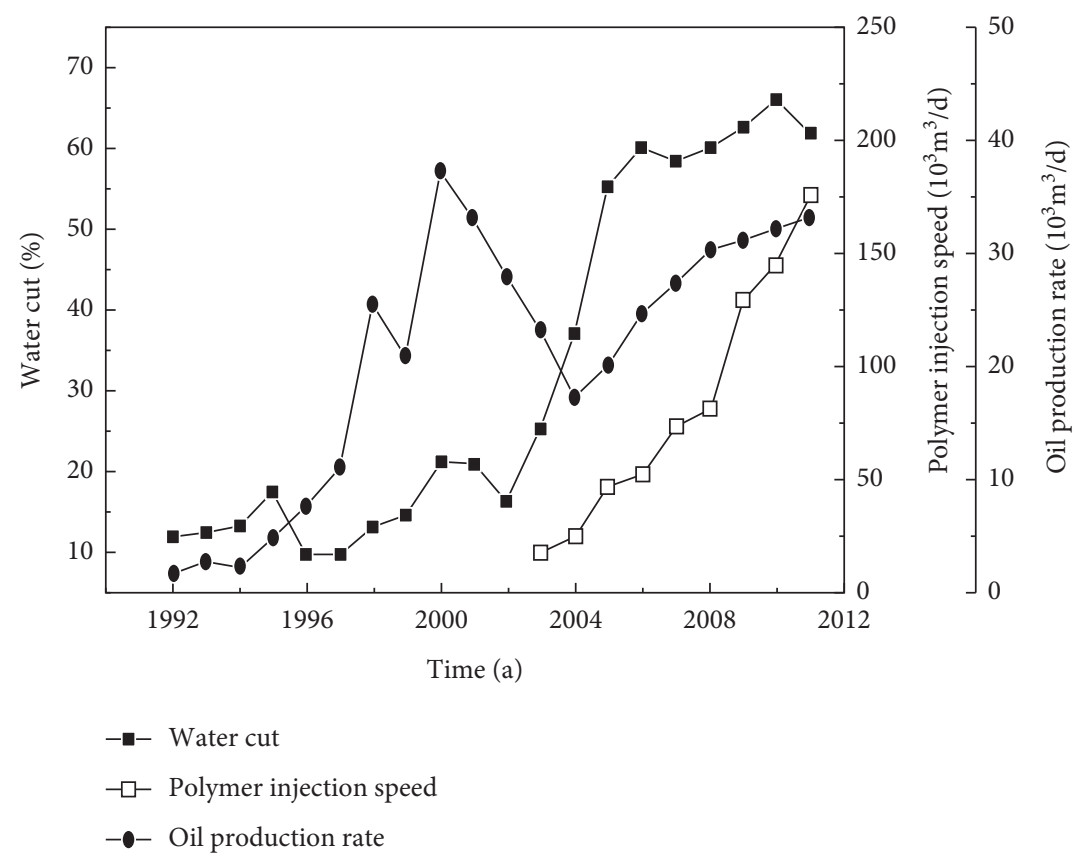

FIgURE 10: Changes in the crude oil production, polymer injection rate, and water cut in block HTLP 6 over time.

continuously injected in 2003, and the oil production began to increase continuously after reaching a trough in 2004 , i.e., from $1.75 \times 10^{4} \mathrm{~m}^{3} / \mathrm{d}$ to $3.25 \times 10^{4} \mathrm{~m}^{3} / \mathrm{d}$ [42].

\subsection{Chemical Viscosity Reduction Development Technique.} This technique involves injecting a chemical viscosity reduction system into a heavy oil reservoir, and the chemical viscosity reduction method is used instead of heating to reduce the viscosity. In contrast to polymer flooding, it mainly acts on the oil phase and improves the development effect by changing the fluidity of the crude oil. In recent years, as cr+ude oil prices have fallen and environmental protection policies have become stricter, the Shengli Oilfield has developed and tested the heavy oil chemical viscosityreducing cold recovery technique. The main development mechanisms are in situ emulsification to improve the percolation capacity of the crude oil and emulsion control and flooding to expand the sweep coefficient [43-47]. Because of its small investment and green environmental protection characteristics, the Shengli Oilfield has been tested and promoted in the Jin 8 and Shang 2 blocks, including sensitive reservoirs, heavy oil reservoirs, low-efficiency water drive heavy oil reservoirs, and deep low-permeability heavy oil reservoirs. Breakthroughs have been made in the development of oil reservoirs and heavy oil reservoirs with edge and bottom water. Since 2018, 384,000 tons of oil have been accumulated, the world's largest heavy oil viscosity reduction cold recovery development base has been constructed, and the scale of the technological development is continuously expanding.

Block Gold 8 is part of a sensitive heavy oil reservoir, with a crude oil viscosity of $1050 \mathrm{MPa}$ s and a clay content of $16.8 \%$. It is characterized by an extremely strong water sensitivity and easy sand production. Natural energy development of this type of oil reservoir requires high-viscosity crude oil, which cannot be recovered. Thermal recovery development has a high clay content, a strong water sensitivity, no injection, a small heating radius, and a rapid production decline. Water flooding development has a high oil-water viscosity ratio, and the production performance is characterized by increasing water but not increasing oil. 
Because a suitable energy supplement formation has not been found for this type of oil reservoir, the production performance is characterized by an energy drop, no injection, and no production. The daily production of a single well is $3.9 \mathrm{t} / \mathrm{d}$, the daily oil production is $1.3 \mathrm{t} / \mathrm{d}$, and the degree of production is only $3.8 \%$. In 2019 , after water flooding, the development technique was switched to chemical viscosity-reducing flooding development. Recovered water was used to prepare the viscosity-reducing system solutions to avoid water sensitivity. The current daily oil production has increased by 1.3 times, and the recovery factor has increased by $6.1 \%$ (Figure 11).

3.3. Microbial Enhanced Oil Recovery. Microbial enhanced oil recovery (MEOR) has a history nearly 100 years long. As early as in the 1920s, in the United States, Beckman put forward the idea of using microbial oil recovery. Beginning in the 1950s, the United States conducted field trials of microbial huff and puff and microbial flooding in the Beverly Hills oil field. Tests were also conducted in the Romashkinskoe oil field in the Soviet Union. Research on microbial oil recovery has been carried out in China since 1960. This technique involves injecting microorganisms and nutrient solutions into the oil layer. These rigorously screened and cultured microorganisms reproduce in situ. The main oil recovery mechanisms are as follows: microbial hydrocarbon-loving viscosity reduction by degrading long-chain alkanes and destroying the molecular structure of colloidal asphaltenes; upgrading the heavy oil and reducing viscosity; using biosurfactants in microbial metabolites to change the wettability of the rock surface, improving the oil displacement efficiency, or acting on the oil-water interface to emulsify the crude oil and reduce the apparent viscosity [48-51].

Compared with other enhanced oil recovery (EOR) techniques, such as gas flooding, chemical flooding, and thermal production, the prominent advantages of MEOR include environmental-friendliness and the lowest cost (Figure 12) [52].

The microbial development technique is currently in a stage of vigorous development, and its application range has been expanding worldwide. Many Chinese oil fields, such as the Daqing, Shengli, and Changqing oil fields, have carried out field applications of microbial development [53-55]. The Zhan 3 block of Shengli Oilfield is a good example of these applications. The recovery degree of this block before microbial flooding was $24.8 \%$, and the comprehensive water cut was 93.8\%. In 2011, microbial flooding was implemented using the endogenous bacteria selective activation oil recovery technique. After six months of implementation, the oil production increased from $24 \mathrm{t} / \mathrm{d}$ to $85 \mathrm{t} / \mathrm{d}$, and the water cut decreased from $96 \%$ to $88.6 \%$ (Figure 13).

\section{Development Direction of Heavy Oil Techniques}

4.1. Thermal Recovery Is Developing towards a Composite Methodology. As the geological conditions of heavy oil development become more complex, single thermal recovery techniques have faced challenges in terms of greatly improving the recovery rate. The thermal compound method has become a development direction in thermal recovery. The thermochemical compound method is used in deep and thin superheavy oil recovery in the Shengli Oilfield. The breakthroughs made in this respect have demonstrated the feasibility of using compound methods. The combination of heat and other media may be the focus of development in the future.

The combination of steam and flue gas is one such method [56-58]. Flue gas $\left(\mathrm{N}_{2} / \mathrm{CO}_{2}\right.$ volume ratio $\left.4: 1\right)$ is produced during the steam production process. Not only does it carry a large amount of enthalpy, but the flue gas itself has the effect of increasing the energy and reducing the viscosity. It is recovered and injected into the oil reservoir, and it can not only improve the development but also reduce emissions. Flue gas and steam combined huff and puff have been applied to 189 wells in the Shengli Oilfield, achieving an increase of 82,000 tons of oil.

Combining steam with a catalytic cracking agent is another such method [59,60]. First, an appropriate injection method is used to preinject the catalyst into the oil layer, and then, it cooperates with the thermal driving conditions generated by the steam heating. The heavy oil reduces the activation energy of the reaction under the action of the catalyst, and a partial cracking reaction occurs. The heavy components are cracked into light components, diluting the heavy oil that has not been cracked, and irreversibly reducing the viscosity of the heavy oil. In addition, because the molecular weight of the heavy oil decreases, the oil grade is improved, and the vapor pressure of the crude oil (oil layer pressure) increases. Seven wells in the Shengli Gudong Oilfield have been produced using catalytic cracking-assisted steam huff and puff, with an average oil increase of 202.6 tons per well.

The combination of steam and solvent is another such method [61-65]. SAGD mainly targets extra-heavy oil and superheavy oil. Its underground crude oil has a viscosity of $>10000 \mathrm{MPa} \mathrm{s}$, but heating the crude oil requires a large amount of steam, which in turn consumes a large amount of natural gas for steam production, which affects the economic benefits of SAGD. In order to reduce the amount of steam and increase the economic benefits of SAGD, Professor Nasr of the Alberta Department of Energy in Canada proposed the solvent-assisted SAGD technique, which combines the steam heating effect and solvent dilution effect to improve the energy efficiency and reduce carbon dioxide emissions. After the solvent and steam are injected into the reservoir together, they are mixed with crude oil in the gas or liquid phase, which has the dual effects of solvent oil viscosity reduction and steam high-temperature viscosity reduction. Xylene is added to dissolve the bitumen, reduce the seepage resistance, and increase the degree of recovery. Foreign mining practices were carried out in Christina Lake. The design took into account the timing of the solvent injection and the well spacing. After half a year of testing, the oil production increased from $100 \mathrm{t} / \mathrm{d}$ to $250 \mathrm{t} / \mathrm{d}$, and the gasoline ratio decreased from 5 to 1.6. At present, there are no reports of relevant practices in China. 


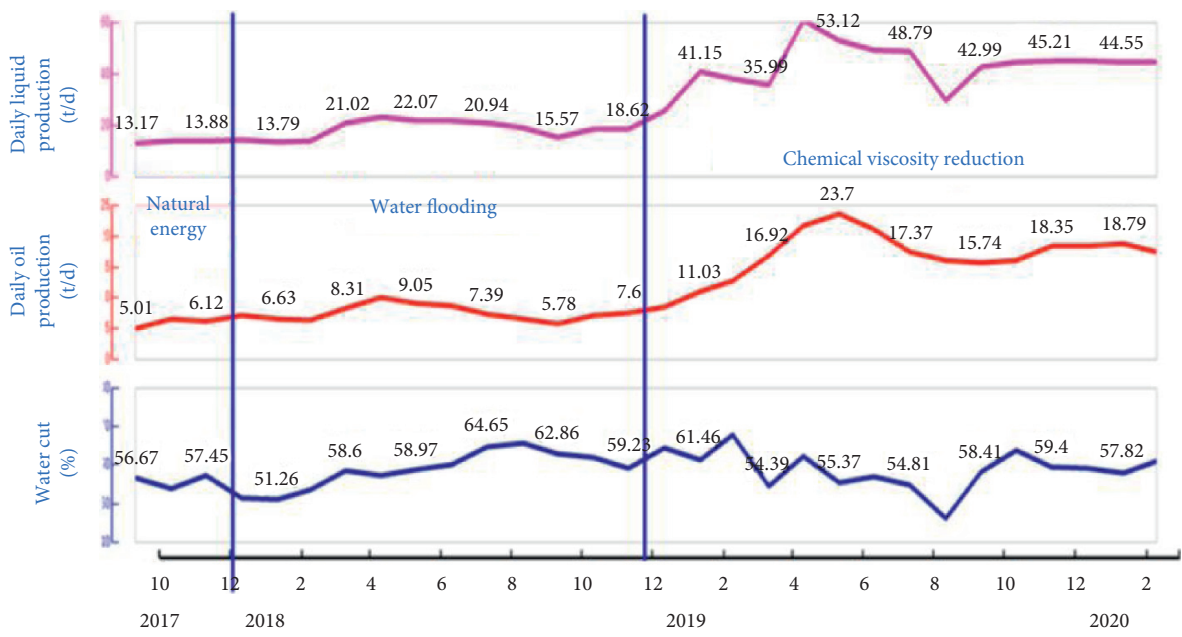

FIGURE 11: Production curve of the chemical viscosity-reducing development of the test well group in the Jin 8 block.

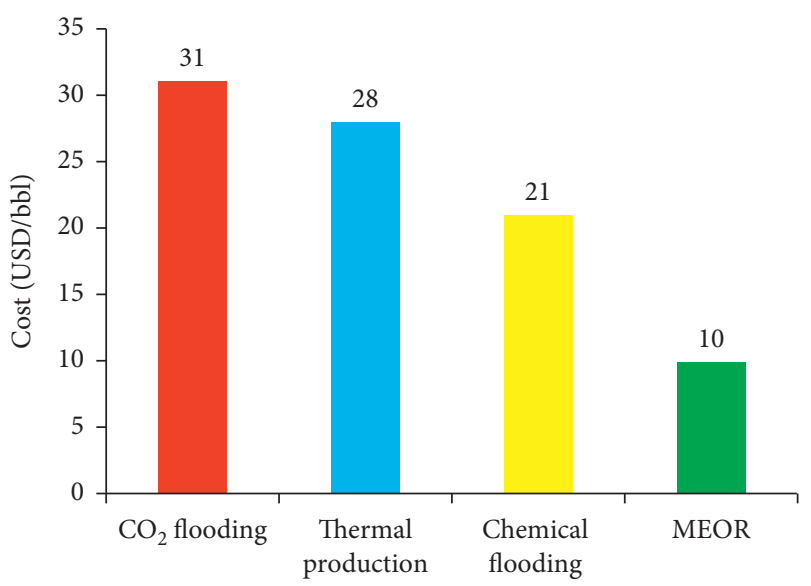

Figure 12: Estimated costs of different EOR techniques.

\subsection{Rapid Development of Heavy Oil Cold Recovery} Techniques. After the sharp decrease in oil prices in 2014, various oil companies put forward the goal of reducing production costs. Moreover, affected by the carbon peak and carbon neutral policy, the development of heavy oil cold recovery techniques has the advantages of low investment and low or no energy consumption. The characteristics of flue gas emissions have received more and more attention.

Heavy oil chemical flooding (polymer flooding, chemical viscosity reduction development) will be an important direction in the future. As was previously mentioned, Canada and China have applied chemical flooding to the development of ordinary heavy oil, and the applied viscosity has been increased from $200 \mathrm{MPa} \cdot \mathrm{s}$ to $2000 \mathrm{MPa}$ s. The scale of chemical viscosity reduction development is continuously expanding in the Shengli Oilfield. In 2018, 2019, and 2020, the oil increases of Shengli Oilfield's chemical viscosity reduction development were 39,000 tons, 102,000 tons, and 146,000 tons, respectively.

$\mathrm{CO}_{2}$ will also be widely used in oil reservoir development under the influence of policies. Because of the high viscosity of heavy oil, it is difficult to achieve miscible flooding. $\mathrm{CO}_{2}$ huff and puff or immiscible flooding is mainly used in huff and puff. The Bati Raman block in Turkey has carried out the world's largest and longest (25 years) deep-fractured heavy oil $\mathrm{CO}_{2}$ immiscible flooding project, and the recovery has increased from $1.5 \%$ to about $10 \%$. The Shengli and Liaohe oil fields in China have both carried out $\mathrm{CO}_{2}$ huff and puff in heavy oil wells, with significant effects.

In addition, various physical oil recovery techniques will also shine under the influence of low-cost targets, including acoustic viscosity reduction technology. Under reservoir temperature conditions, depending on the increase in the sound wave power and action time, the sound wave viscosity reduction rate can reach $90 \%$. Research has shown that the combination of sonic waves and a viscosity reducer has a better viscosity reduction effect or achieves the same viscosity reduction effect. The combined viscosity reduction only requires $50 \%$ of the amount of chemical agent, which greatly reduces the cost [66-69].

The vapor extraction (VAPEX) production technique uses light hydrocarbons or a mixture of light hydrocarbons and noncondensable gas to replace steam and extract heavy oil or bitumen. Compared with thermal recovery, the VAPEX method can be implemented under reservoir temperature conditions without heat loss. Bottom water, high water cut, vertical cracks, low porosity, low conductivity, heavy oil, and asphalt reservoirs are not suitable for thermal recovery. However, the VAPEX method can be used. VAPEX is unique and has great potential in field applications. At present, all of the research on this technique is still in the experimental stage, and the research mainly focuses on the following two aspects: the precipitation of asphalt and its influence on permeability and the ratio of the solvent injection and crude oil produced during economic and effective development [70-74].

4.3. Rapid Application of Nanomaterials in the Development of Heavy Oil. Nanoscale particles are characterized by small size, large specific surface area, high surface energy, and a 


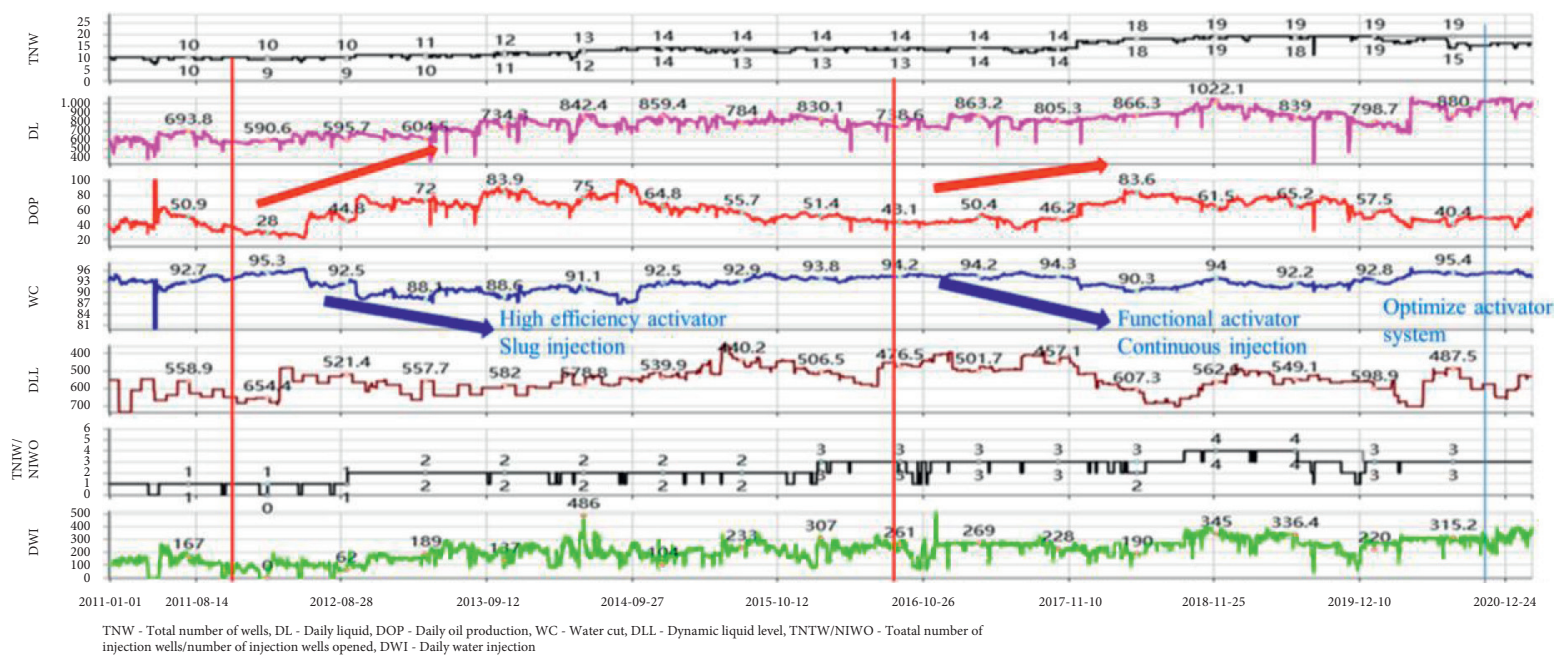

FIGURE 13: Oil recovery curve for microbial flooding in the Zhan 3 block in the Shengli Oilfield.

large proportion of surface atoms, so they have unique physical and chemical properties such as surface effects, small-sized effects, and macroscopic quantum tunneling effects. The integration of nanotechnology and enhanced oil recovery can solve problems that traditional EOR techniques cannot solve, such as low efficiency, poor adaptability to harsh environments, and potential reservoir damage. The research idea of nanointelligent oil displacement technology is as follows: the nano-oil displacement agent is small enough to basically achieve full reservoir spread; the strongly water-repellent and stronglipophilic characteristics repel the water, and the agent has an affinity for oil and is self-driven. It can achieve intelligent oil search. Dispersed oil merging can capture dispersed oil to form an oil wall or oil-rich zone and be driven out [75-79]. At present, nanomaterials have two application directions in heavy oil recovery: one is as a nano-oil displacement agent. Hou et al. invented a nano-oil displacement agent called Heika, which was tested with crude oil from multiple blocks, including the Liaohe and Shengli blocks. The viscosity reduction rate was more than $99 \%$, and the core flooding experiment showed that the recovery rate can be increased by more than $14 \%$ after water flooding [77]. The other application is as a nano-catalyst, which uses the unique properties of nanomaterials to reduce the catalytic cracking temperature and expand the catalytic cracking of the reservoir. To achieve synergy with thermal recovery under reservoir conditions, nanomaterials are currently moving from the laboratory to field tests. China's G4 heavy oil block uses a nanodisplacing agent $+\mathrm{CO}_{2}$ huff and puff, and the daily oil production in this block has reached $6 \mathrm{t} / \mathrm{d}$.

\section{Conclusions}

(1) Heavy oil thermal recovery techniques are mature. After nearly 100 years of development, four basic technical forms have been developed: steam huff and puff, steam-driven, SAGD, and fire-driven. China has developed and implemented two techniques, i.e., the thermochemical compound and multielement thermal fluid techniques, which solved the problems of deep/thin layer and offshore heavy oil development. At present, these six techniques are the main technical means of heavy oil development.

(2) Heavy oil cold recovery is currently in the development stage. Polymer flooding, chemical viscosity reduction development, and microbial oil recovery have been tested in the field and have achieved certain results. However, polymer flooding above $200 \mathrm{MPa}$ s has the problems of difficult injection and high chemical agent costs. The mechanisms and development effects of chemical viscosity reduction development and microbial oil recovery still need to be studied further and observed.

(3) Due to the more complex geological conditions of heavy oil development and the influence of policies, single thermal oil recovery techniques face challenges in greatly enhancing oil recovery. A variety of techniques and new materials will be applied to heavy oil development. Thermal composite, cold production development, and the application of nanomaterials will be the three trends of heavy oil development in the future.

\section{Data Availability}

The data used to support the findings of this study are available within the article.

\section{Conflicts of Interest}

The authors declare that there are no conflicts of interest regarding the publication of this article.

\section{Acknowledgments}

This study was supported by the National Natural Science Foundation of China (No. 51774256). 


\section{References}

[1] F. Ma, G. Y. Zhang, H. J. Wang et al., "Global heavy oil and oil sands resource potential, distribution and exploration direction," Journal of Jilin University (Earth Science Edition), vol. 45, no. 4, p. 1042, 2015.

[2] X. L. Shan, C. B. Che, J. Li, C. Y. Fan, C. Y. Zang, and Q. B. Wang, "Research status of oil sand resources at home and abroad," World Geology, vol. 26, no. 4, pp. 459-464, 2007.

[3] L. D. Yu, "The distribution of the world's heavy oil resources and the status quo and prospects of their exploitation technologies," Special Oil \& Gas Reservoirs, vol. 8, no. 2, pp. 98-103, 2001.

[4] D. W. Wang, N. Q. Zhou, and K. Mou, "Current status and development trend of heavy oil thermal recovery technology," Western Exploration Engineering, vol. 12, pp. 129-131, 2008.

[5] F. X. Ren, H. J. Sun, and C. H. Hu, "Heavy oil development technology and practice in Liaohe oilfield," Special Oil \& Gas Reservoirs, vol. 19, no. 1, pp. 1-8, 2012.

[6] Z. H. Zhang, Current Status of Heavy Oil Development at Home and Abroad and Development Trend of Heavy Oil Development Technology, PetroChina Exploration and Development Research Institute, Beijing, China, 2005.

[7] B. Xiong, H. Zhang, H. Z. Li, and Z. Z. Zhao, "Heavy oil recovery technology and prospects," Chemical Engineering and Equipment, vol. 2016, no. 2, pp. 169-171, 2016.

[8] X. Z. Wang, "Progress in heavy oil exploitation technology," Contemporary Petroleum and Petrochemical, vol. 18, no. 1, pp. 26-29, 2010.

[9] G. H. Wu and Z. P. Liu, "Research progress on thermal recovery and development technology of heavy oil in Shengli oilfield," Contemporary Petroleum and Petrochemical, vol. 22, no. 12, pp. 7-11, 2014.

[10] T. X. Guo and Y. C. Su, "Development status and technical development direction of heavy oil reservoirs in Bohai Oilfield," China Offshore Oil and Gas, vol. 25, no. 4, pp. 26-30, 2013.

[11] Y. M. Chen, Thermal Oil Extraction by Steam Injection, Petroleum University Press, Dongying, China, 1996.

[12] Y. Wu, "Liaohe Oilfield development technology thoughts and suggestions field," Special Oil \& Gas Reservoirs, vol. 25, no. 6, pp. 96-100, 2018.

[13] F. X. Chang, Y. Z. Qi, Y. J. Zhang et al., " $\mathrm{CO}_{2}$ assisted steam flooding in late steam flooding in heavy oil reservoirs," $\mathrm{Pe}$ troleum Exploration and Development, vol. 46, no. 6, pp. 1242-1250, 2019.

[14] D. Du, Y. Zhang, X. Liu, L. Zhang, L. Ren, and P. Liu, "New gas tracer convection-diffusion model between wells in heavy oil reservoirs," ACS Omega, vol. 6, no. 38, pp. 24752-24764, 2021.

[15] H. Y. Zhao, M. X. Ge, and H. Zhang, "Research and application of super heavy oil steam flooding technology boundary in Liaohe Oilfield," Special Oil \& Gas Reservoirs, vol. 10, no. 13, 2020.

[16] L. Zhang, W. X. Du, and P. Xiao, "High-efficiency lifting technology for steam flooding production wells in Shengli Oilfield," Petroleum Drilling Technology, vol. 46, no. 4, pp. 91-95, 2018.

[17] D. L. Zhao, Research on Integrated Injection-Production Technology of Cheng 91 Block Super Heavy Oil Reservoir, China University of Petroleum, Qingdao, China, 2016.

[18] A. Velayati and A. Nouri, "Emulsification and emulsion flow in thermal recovery operations with a focus on SAGD operations: a critical review," Fuel, vol. 267, no. 1, pp. 117-141, 2020 .
[19] L. F. Geng, "Research on SAGD technology for dual-horizontal wells in super heavy oil in Liaohe Oilfield," Special Oil \& Gas Reservoirs, vol. 14, no. 1, pp. 47-53, 2007.

[20] D.-F. Du, Y.-Z. Zhang, L.-N. Zhang, M.-R. Xu, and X. Liu, "Expansion velocity model of steam-assisted gravity drainage considering thermal convection," Geofluids, vol. 2021, Article ID 9925410, 12 pages, 2021.

[21] D. Srinivasareddy and G. S. Kumar, "A numerical study on phase behavior effects in enhanced oil recovery by in situ combustion," Petroleum Science and Technology, vol. 33, no. 3, pp. 353-362, 2015.

[22] I. Y. Akkutlu and Y. C. Yortsos, "Steady-state propagation of in-situ combustion fronts with sequential reactions," in Proceedings of the SPE International Petroleum Conference in Mexico, Puebla Pue., Mexico, 2004.

[23] D. C. Shallcross, Devices and Methods for In-Situ Combustion Ignition, Stanford University Petroleum Research Institute, Stanford, CA, USA, 1989.

[24] Y. J. Wang, J. C. He, G. Z. Liao, and Z. M. Wang, "Development history and application prospects of domestic fire flooding technology," Acta Petrolei Sinica, vol. 33, no. 5, pp. 909-914, 2012.

[25] G. Fan, J. Xu, M. Li, T. Wei, S. M. M. Nassabeh, and N. Mohammad Mehdi, "Implications of hot chemical-thermal enhanced oil recovery technique after water flooding in shale reservoirs," Energy Reports, vol. 6, pp. 3088-3093, 2020.

[26] O. S. Alade, H. Mohamed, M. Mahmoud et al., "A preliminary assessment of thermochemical fluid for heavy oil recovery," Journal of Petroleum Science and Engineering, vol. 186, Article ID 106702, 2020.

[27] H. Q. Sun, "The method and technology of thermochemical composite oil recovery for thin reservoir super heavy oil," Petroleum and Gas Geology, vol. 41, no. 5, pp. 1100-1106, 2020.

[28] P. Liu, W. Li, D. Shen, and H. T. Qian, "Experimental study and pilot test of urea- and urea-and-foam-assisted steam flooding in heavy oil reservoirs," Journal of Petroleum Science and Engineering, vol. 135, pp. 291-298, 2015.

[29] J. Wang, H. Q. Liu, Z. L. Wang, G. H. Peng, and S. M. Lai, "Numerical simulation study of thermal foam combination flooding in heavy oil reservoirs," Special Oil \& Gas Reservoirs, vol. 18, no. 5, pp. 75-78, 2017.

[30] B. F. Li, J. G. Zhang, L. Tao, Z. M. Li, and Y. Wang, "Research on high-efficiency production technology of super heavy oil HDCS," Drilling and Production Technology, vol. 32, no. 6, pp. 52-55, 2009.

[31] J. Z. Wang, X. Z. Wang, K. Liu, and H. B. Shen, "Evaluation of pilot test effect of shallow super heavy oil HDNS technology in Pai 601 block of Chunfeng Oilfield," Special Oil \& Gas Reservoirs, vol. 18, no. 4, pp. 59-62, 2011.

[32] J. F. Sun, "Nitrogen and viscosity reducers assisted horizontal well thermal recovery to develop shallow and thin ultra-heavy oil reservoirs," Petroleum Geology and Recovery Efficiency, vol. 19, no. 2, pp. 47-53, 2012.

[33] G. Z. Lu and J. Q. Zhang, "Research on the technology of nitrogen foam hot water flooding to enhance the recovery of heavy oil," Journal of Oil and Gas Technology, vol. 27, no. 2, pp. 387-388, 2005.

[34] G. C. Liu, "Research on Bohai sea heavy oil multi-element thermal fluid huff and puff technology," Journal of Yangtze University (Self Science Edition), vol. 11, no. 10, pp. 99-103, 2014.

[35] T. T. Ge, Z. X. Pang, C. D. Luo, Z. N. Gao, and C. X. Du, "Physical simulation experiment of multi-element thermal 
fluid flooding for horizontal wells in offshore heavy oil reservoirs," Petroleum Geology and Recovery Efficiency, vol. 26, no. 4, pp. 62-69, 2019.

[36] S. Huang, M. Cao, and L. Cheng, "Experimental study on the mechanism of enhanced oil recovery by multi-thermal fluid in offshore heavy oil," International Journal of Heat and Mass Transfer, vol. 122, pp. 1074-1084, 2018.

[37] Q. L. Zhang, Y. T. Han, Y. Chen, J. Li, L. X. Jia, and S. Ma, "Study on the optimization of offshore multi-element thermal fluid parameters and well selection principles," Petroleum Exploration and Development, vol. 38, no. 4, pp. 71-77, 2020.

[38] L. Wang, W. Zheng, H. J. Yu, X. G. Liu, J. Tang, and N. Li, "Evaluation of multi-round huff and puff development effect of Bohai heavy oil multi-element thermal fluid," Journal of Chongqing University of Science and Technology (Natural Science Edition), vol. 18, no. 4, pp. 29-32, 2016.

[39] H. H. Pei, G. C. Zhang, J. J. Ge, Q. H. Liu, Y. Wang, and C. Wang, "Research progress of chemical flooding to improve the recovery of ordinary heavy oil," Oilfield Chemistry, vol. 27, no. 3, pp. 350-356, 2010.

[40] X. S. Zhang and M. A. Ding, "Research on key reservoir conditions of polymer flooding in continental sedimentary heavy oil reservoirs," Journal of Oil and Gas Technology, vol. 31, no. 1, pp. 127-129, 2009.

[41] J. F. Xu, L. S. Cheng, and C. T. Li, "Evaluation of the adaptability of ordinary heavy oil ultra-high molecular polymer flooding," Petroleum Drilling and Production Technology, vol. 29, no. 3, pp. 63-68, 2007.

[42] X. L. Cao, Z. Q. Li, H. J. Gong, M. Z. Dong, and Y. J. Li, "Research progress and application of heavy oil polymer flooding in Canada," Oilfield Chemistry, vol. 32, no. 3, pp. 461-466, 2015.

[43] S. J. Allenson, A. T. Yen, and F. Lang, "Application of emulsion viscosity reducers to lower produced fluid viscosity," Offshore Technology Conference, vol. 22443, 2011.

[44] V. R. Guillen, M. S. Carvalho, and V. Alvarado, "Pore scale and macroscopic displacement mechanisms in emulsion flooding," Transport in Porous Media, vol. 94, no. 1, pp. 197-206, 2012.

[45] M. Moradi, M. Kazempour, J. T. French, and V. Alvarado, "Dynamic flow response of crude oil-in-water emulsion during flow through porous media," Fuel, vol. 135, pp. 38-45, 2014.

[46] M. T. Bao, X. N. Fan, Q. F. Cao, A. Q. Ma, and X. X. Guo, "Research progress in viscosity reduction technology for heavy oil production," Oilfield Chemistry, vol. 23, no. 3, pp. 284-288, 2006.

[47] Y. X. Chen, X. Wang, C. S. Pan, and D. R. Lu, "Application of surfactants in viscosity reduction of heavy oil," Journal of Chongqing University of Science and Technology (Natural Science Edition), vol. 11, no. 1, pp. 48-50, 2009.

[48] T. E. Vadivel, S. K. Periyasamy, and S. Naiyf, "Swift production of rhamnolipid biosurfactant, biopolymer and synthesis of biosurfactant-wrapped silver nanoparticles and its enhanced oil recovery," Saudi Journal of Biological Sciences, vol. 4 , no. $1,2020$.

[49] Z. Hamed, J. Arezou, S. Mohammad Mousavi, and E. Darezereshki, "Biosynthesis of silica nanoparticle using Saccharomyces cervisiae and its application on enhanced oil recovery," Journal of Petroleum Science and Engineering, vol. 7, Article ID 107002, 2020.

[50] A. Hakan, S. Martina, and D. Nicole, "Investigation of spontaneous imbibition induced by wettability alteration as a recovery mechanism in microbial enhanced oil recovery,"
Journal of Petroleum Science and Engineering, vol. 182, Article ID 106163, 2019.

[51] H. Q. Shi, F. Shi, Q. He, Z. Wang, and Z. F. Liang, "Research on microbial flooding technology of surfactant-producing bacteria and the effect of enhancing oil recovery," Petroleum Drilling and Production Technology, vol. 42, no. 4, pp. 438443, 2020.

[52] H. She, D. Kong, Y. Li, Z. Hu, and H. Guo, "Recent advance of microbial enhanced oil recovery (MEOR) in China," Geofluids, vol. 2019, Article ID 1871392, 16 pages, 2019.

[53] Z. Huang, W. Sun, and Z. Dong, "Diversity analysis after microbial flooding in ultra-low permeability reservoirs: taking Chang 6 reservoir in Ansai Oilfield as an example," Petrochemical Industry Application, vol. 36, no. 11, pp. 12-15, 2017.

[54] F. P. Ren, G. Wang, J. You, Y. D. Wu, Y. T. Pei, and Z. H. Shao, "Study on the succession of microbial community in the process of microbial oil production in Baolige Oilfield," Oilfield Chemistry, vol. 34, no. 2, pp. 318-322, 2017.

[55] H. B. Shen and H. Zhao, "Research on the optimization of microbial flooding indoor test and on-site injection technology - taking the south area of Pai 6 of Chunfeng Oilfield as an example," Energy Conservation in Petroleum and Chemical Industry, vol. 03, pp. 33-44, 2017.

[56] Y. Wang, Research on Improving the Effect of Heavy Oil Development with Flue Gas Assisted SAGD, China University of Petroleum, Qingdao, China, 2010.

[57] F. S. Wang, Z. B. Mou, and P. C. Liu, "Experimental and numerical simulation of $\mathrm{CO}_{2}$ assisted production mechanism in super-heavy oil reservoirs," Petroleum Geology and Recovery Efficiency, vol. 24, no. 6, pp. 86-91, 2017.

[58] C. Wang, P. Liu, F. Wang, B. Atadurdyyev, and M. Ovluyagulyyev, "Experimental study on effects of $\mathrm{CO}_{2}$ and improving oil recovery for $\mathrm{CO}_{2}$ assisted SAGD in superheavy-oil reservoirs," Journal of Petroleum Science and Engineering, vol. 165, pp. 1073-1080, 2018.

[59] Y. J. Liu, L. G. Zhong, S. J. Jiang, X. L. Sun, and N. N. Gong, "Research progress in hydrothermal cracking technology for heavy oil production," Journal of Fuel Chemistry and Technology, vol. 32, no. 1, pp. 117-122, 2004.

[60] C. Wu, G. L. Lei, C. J. Yao, P. Y. Gai, Y. B. Cao, and X. N. Li, "Research on viscosity reduction mechanism of super heavy oil hydrothermal cracking with amphiphilic catalyst," Journal of Fuel Chemistry and Technology, vol. 6, 2010.

[61] Y. B. Wu, X. Q. Liu, and X. Du, "Physical simulation experiment on the mechanism of solvent-assisted gravity drainage in super heavy oil reservoirs," Petroleum Exploration and Development, vol. 47, no. 4, pp. 765-771, 2020.

[62] C. Egboka and D. Y. Yang, "Performance of a SAGD process with addition of $\mathrm{CO}_{2}, \mathrm{C}_{3} \mathrm{H}_{8}$, and $\mathrm{C}_{4} \mathrm{H}_{10}$ in a heavy oil reservoir," Society of Petroleum Engineers of AIME, vol. 150170, 2011.

[63] T. Babadagli and B. Ozum, "Biodiesel as surfactant additive in steam assisted recovery of heavy-oil and bitumen," Society of Petroleum Engineers of AIME, vol. 133376, 2010.

[64] L. Wang, "Research on multi-medium combined gravity drainage (SAGP) technology in Liaohe oilfield," China Foreign Energy, vol. 17, pp. 50-53, 2012.

[65] J. Luo, X. L. Li, H. Z. Wang, and H. Liu, "A review of research on solvent-assisted steam gravity drainage technology," $P e$ troleum Drilling and Production Technology, vol. 36, no. 3, pp. 106-110, 2014.

[66] D. L. Xu, J. B. Gao, C. Li, W. J. Lin, and Y. C. Zang, "Experimental study on the application of ultrasonic to reduce 
viscosity of heavy oil," Acoustic Technology, vol. 39, no. 6, pp. 682-685, 2020.

[67] D. L. Zhang and Y. C. Dai, "The effect of ultrasound on the viscosity and viscosity-temperature properties of heavy oil," Contemporary Chemical Industry, vol. 40, no. 9, pp. 885-887, 2011.

[68] K. S. Susliek, The Chemical Effects of Ultrasound, Scientific American, New York, NY, USA, 1989.

[69] H. X. Xu, C. S. Pu, Q. L. Dong, and M. J. Hu, "Experimental study on low-temperature cracking of ultra-heavy oil with ultrasonic synergistic catalyst," Applied Chemical Industry, vol. 41, no. 7, pp. 1143-1146, 2012.

[70] F. J. Zhao and G. D. Wang, "Development status and analysis of VAPEX technology for heavy oil and asphalt at home and abroad," Chemical Industry Progress, vol. 31, no. 2, pp. 304309, 2012.

[71] F. J. Zhao, Y. J. Liu, and Y. B. Wu, "Research progress on the influence factors of heavy oil and asphalt VAPEX technology," Chemical Industry Progress, vol. 31, no. 7, pp. 1477-1483, 2012.

[72] J. Shi and J. Y. Leung, "Physics-based proxy modelling of solvent transport in VAPEX process," Canadian Journal of Chemical Engineering, vol. 92, no. 8, pp. 1467-1480, 2014.

[73] N. Rezaei, O. Mohammadzadeh, L. A. A. James, and I. Chatzis, "Experimental investigation of the VAPEX process in vuggy porous media," SPE Journal, vol. 19, no. 1, pp. 101-108, 2014.

[74] N. Rezaei, Experimental Investigations in Improving the VAPEX Performance for Recovery of Heavy Oil and Bitumen, University of Waterloo, Waterloo, Canada, 2010.

[75] J. C. Wu, F. Shi, Y. Zhao, M. X. Zhang, and L. Y. Cai, "Research progress of functional nano-oil displacement agents," Journal of Northeast Petroleum University, vol. 44, no. 5, pp. 70-75, 2020.

[76] S. Fang, J. C. Wu, and B. Zhao, "Preparation and investigation of intelligent polymeric nanocapsule for enhanced oil recovery," Materials, vol. 12, pp. 1093-1114, 2019.

[77] J. R. Hou, Y. C. Wen, M. Qu, T. Liang, W. P. Wu, and Y. T. Ding, "Research and application of nanomaterials to improve oil and gas recovery," Special Oil \& Gas Reservoirs, vol. 10, p. 10, 2020.

[78] Z. L. Liu, V. Bode, P. Hadayati, H. Onay, and E. J. R. Sudhölter, "Understanding the stability mechanism of silica nanoparticles: the effect of cations and EOR chemicals," Fuel, vol. 280, Article ID 118650, 2020.

[79] B. Wei, Q. T. Tian, R. X. Mao, Y. Xue, Y. B. Wen, and W. F. Pu, "Application and prospect of nano-cellulose materials in oil and gas field development," Petroleum Geology and Recovery Efficiency, vol. 27, no. 2, pp. 98-104, 2020. 